\title{
A Structured Skills Training under Professional Education in "Credit Management” Applied Undergraduate Institutions
}

\author{
Yun Yang ${ }^{1, a, ~}$, Yuhan Wang ${ }^{1, b}$ \\ ${ }^{1}$ School of Economics \& Management, Shanghai Polytechnic University, Pudong, Shanghai, China \\ ayangyun@sspu.edu.cn, byhwang@sspu.edu.cn \\ *Yun Yang
}

Keywords: Professional education, Skills, Credit management, Applied undergraduate institutions, curriculum mapping.

\begin{abstract}
Global uncertainty and heavy competition requires companies to remain effective in investments and sensible in people development. Employers consistently place high value on graduates that have demonstrated relevant skills and knowledge. For acquiring such relevant capabilities, and avoiding "undifferentiated" Students in Applied Undergraduate Education, a skills training program geared towards professional ideals should be designed. A qualitative study using curriculum mapping was conducted, as well as interviewing teaching staff members, employers, enterprise staffs, and students. This paper outlines a structured skills training framework which links learning objectives to desired business results. As one of "soft science"-"Credit management", this professional skills training should be composed of three parts: theoretical training based on practice, job training (or post practice), and professional extension ability practice. At the same time, applicable tools were used in specific practical courses. Employment status showed that the structured skills training improved the students' professional skill, reduced the cost of companies in training, and enhanced students' competitiveness in the labor market.
\end{abstract}

\section{Introduction}

With the development of higher education in China, the education of applied undergraduate talents has become a national concern. It was proposed that we should focus on expanding the scale of applied, compound, skilled training in "The National Medium and Long-term Education Reform and Development Plan (2010-2020)” (MOE, 2010). But at present, the education of applied undergraduates still cannot support the market demand and the industrial development in part of professional settings, courses, and skills training (MOE,2015). In a survey, the employer evaluates the applied undergraduate talents from three dimensions: ideological quality (such as social responsibility and legal knowledge), professional quality (such as professional skill, professional knowledge and interpersonal skills) and support quality (such as health). The score of professional quality was found to be the lowest out of the three. Comparing the employer's expected value of the graduates' professional quality with the actual value, they found that the expectations of all aspects of the professional quality were higher than the actual value; the exception being the professional knowledge and innovation ability (Pan \& Liao, 2014). Thus, improving students' professional ability is becoming an urgent problem.

Curriculum mapping is an instrumental concept of curriculum development and management. Laura Delgaty stated that if education was considered a journey, teachers should have some resources to provide guidance and direction to students, and curriculum mapping is such a tool (Delgaty, 2009). Curriculum mapping has been emphasized in recent higher education curriculum innovation, in the drive for global competitiveness. There are also various universities in China that have begun to utilize it (Wang, 2015; Gong \& Xiao, 2015). As a visual tool, the curriculum map should contain at least two levels: the unit or course level and the "whole of curriculum" level.

Based on the idea of curriculum mapping, this paper lists the talent training goals (in other words, the student learning outcomes), structures a skills training framework, and builds a skills training 
curriculum structure at the "whole of curriculum" level for credit management.

\section{Definition of the Talents Training Goals}

According to the employer's evaluation of applied undergraduates and the social demand, we believe that the talent training goals in the soft science should be progressive goals. This includes "content oriented, ability oriented, and active learning".

\subsection{Content Oriented}

The goal of content orientation is to help students master certain professional knowledge by learning. Any talent training program must first have a theoretical curriculum system that can meet the professional knowledge structure, as well as cultivate students' "relearning ability" and "professional malleability". Under such a curriculum system, the student's professional knowledge foundation can be complete. This theoretical curriculum system must be well-designed and constantly modified around the professional direction.

However, through the study of this theoretical curriculum system, students' professional knowledge is often scattered. Some students may have thoughts such as, "What is the use of this course?”, "I have learned so many courses, but I do not know what I can do in the future”, " I seem to know everything, but what is my major interest?", "Who can give me guidance on how to get a job which I like and can be competent in?". Such problems are very difficult to solve by a perfectly designed theoretical curriculum system.

\subsection{Ability Oriented}

To solve the above problems, we need to cultivate students' various abilities. According to the research of Yuju Pan and Chuanjing Liao, the main abilities are professional skills, problem solving skills, team cooperation ability, innovation ability, writing ability, understanding ability, self-learning ability, communication ability, strain capacity, implementation and organization and coordination ability (Pan \& Liao, 201).

In an ability oriented curriculum, professional practices should be incorporated into the entire teaching procedure. With a lot of practice teaching content, professional skills are being cultivated, and students develop their ability to link knowledge and practice. Gradually, students will have a series of ideas, such as "I know the use of the course learned before", " I seem to understand the relationship between courses", "Why we learned this in class is not the same in practice", "My accumulation of professional knowledge is not enough", and so on.

\subsection{Active Learning}

Students should not be made "to learn”, but “are learning” (Wang, 2015). By combining certain practical and theoretical teaching, students will gradually find their own specialty professional development which can meet their desires and suit their personalities. After finding their direction and what they really want to do, students will gain great curiosity, and then will transfer from "to learn" to "learning”.

They will be eager to find and learn more suitable, advanced, and complete theory to solve problems in practice. At the same time, they will also propose: "Why is it that what the text book says is unlike the operation method in the practice? Who is wrong?" With such doubt, they will solve these problems by poring over documents, reading books, asking teachers, seniors, and even peer acquaintances, friends. Thus, the ultimate goal of professional education is realized - they are learning actively. Once the goal of active learning is realized, we have reason to believe that students will be able to learn actively and stretch their capabilities even after graduating.

Clearly, in such a three-stage progressive training goal, "Ability oriented" becomes the necessary stage in transition from the first layer to the ultimate goal. If without the middle goal of "ability oriented", it is hard to reach the "active learning" level. In other words, if the teaching process is limited to a classroom with a text book, without including skills training, the students will be trained with repeated memorization, and become a copy and paste machine, rather than becoming 
talented students who can integrate knowledge and skills. This will then create the lack of core competence in the competition.

Therefore, the design of skills training is related to the quality of applied professional education in "soft science".

\section{Framework Building}

The idea of "curriculum mapping” provides guidance and direction to students (Delgaty, 2009). Depending on the previous analysis of talents training goals or outcomes, this professional skills training is composed of three parts: theoretical training based on practice, job training (or post practice), and professional extension ability practice (figure 1).

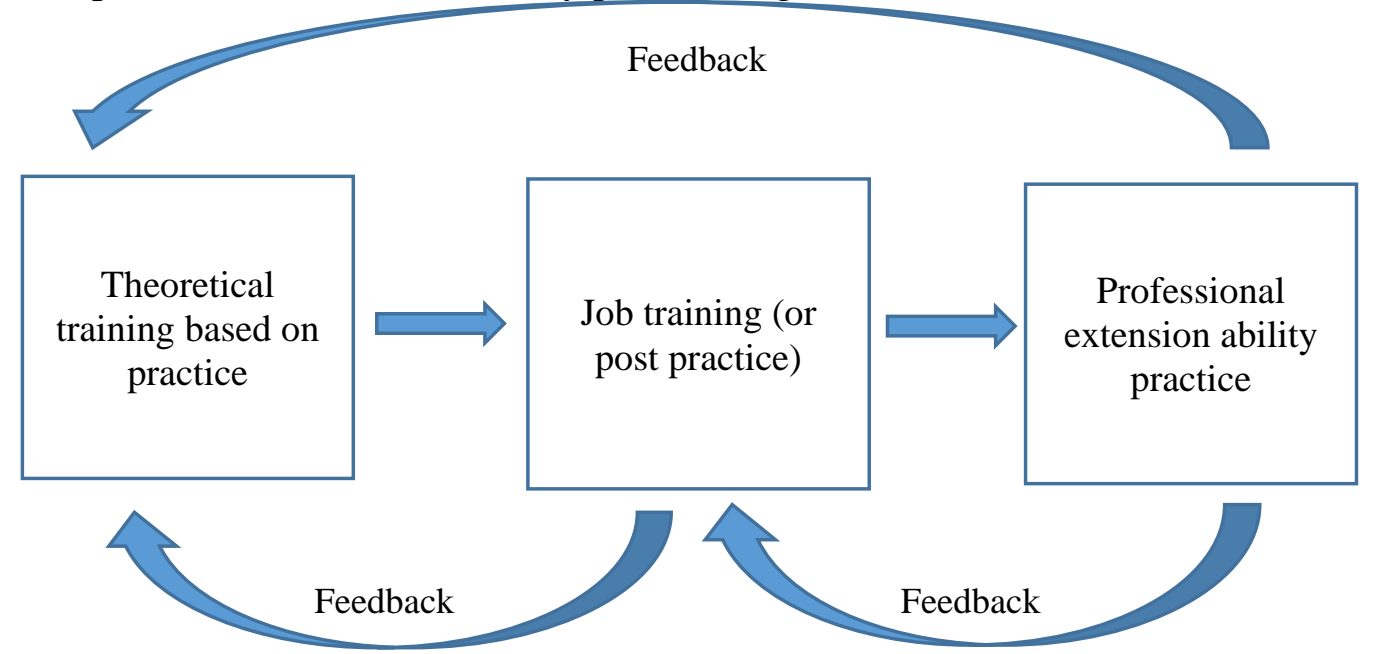

Figure 1 Skills Training Framework (Source: Wang, 2014:390).

\subsection{Theoretical Training Based on Practice}

Theoretical training based on practice is designed for the general basic course. The first objective is to deepen students' understanding of basic theory, by using the theory to analyze problems. The second is to improve students' awareness of professional ideals.

\subsection{Job Training (or Post Practice)}

This is the core of the framework. In the concept of "curriculum mapping”, curriculum planning guides students with employment and development direction, and shows how the courses are related to a future career. In a four-year applied undergraduate education program, it is not realistic that the skills training would be located on a whole employment post cluster. Therefore, applied undergraduate education in "soft science" should have a clear direction of professional training, rather than focusing on the whole. It can be distinguished from other similar colleges and universities. So, 2-3 post groups should be identified according to the professional direction. The practice is also designed according to their post. It is necessary to divide the students in the same major into several sub-groups to practice. Through the job training, student will meet the employer's professional quality requirements easier.

\subsection{Professional Extension Ability Practice}

In this area, instead of being divided into groups by job group and model, students would learn together. The practical skills of students are integrated and promoted by "group discussion", "comprehensive cases", and "simulating the real environment".

\subsection{Feedback}

In the framework, there are three feedback flows. One is feedback from job training (or post practice) to theoretical training based on practice. Another is feedback from professional extension ability practice to job training (or post practice). The third one is feedback from professional 
extension ability practice to theoretical training based on practice.

Every feedback has two levels. For students, the feedback lets them know of how much professional knowledge they lack, which skills they need to improve, and encourages students to study actively. For teachers, in order to meet demands for talents training better, they can modify the curriculum plan and course plan according to the feedback.

\section{Skills Training Curriculum Structure Practice in Credit Management}

\subsection{Definition of Credit Management Talents Training Goals: Five Abilities}

By integrating the study of others (Zhou, 2013; Pan \& Liao, 2014; Watts \& Hodgson, 2015)and interviewing with teaching staff members, employers, enterprise staffs, and students related to credit management, the goals of credit management talents training with five abilities are definite.

Table 1 Five abilities of credit management talents training.

\begin{tabular}{|l|l|}
\hline Ability & Description \\
\hline Basic ability & $\begin{array}{l}\text { Language and writing skills, statistics software usage, } \\
\text { observation and investigation, legal knowledge }\end{array}$ \\
\hline Interpersonal ability & Team cooperation skills, communication skills \\
\hline Professional skills & $\begin{array}{l}\text { Specific job skills related to credit management } \\
\text { positions }\end{array}$ \\
\hline Innovation ability & $\begin{array}{l}\text { Find and define problems; solve and present solutions } \\
\text { to problems; reproduce or solve problems; }\end{array}$ \\
\hline Comprehensive ability & $\begin{array}{l}\text { Integrate comprehensive knowledge and skills to solve } \\
\text { various problems }\end{array}$ \\
\hline
\end{tabular}

\subsection{Professional Direction and Job Analysis}

Credit management can be divided into four professional directions: enterprises, financial institutions, professional organizations and government agencies. Each direction can be divided into three levels: primary, intermediate and advanced (Zhou, 2013). With regards to the social demand, the first three directions are the most in demand. Education of an undergraduate level can meet the requirements of most of the posts. Some jobs, such as file management and business account recovery, can be met by college education. Parts of jobs in credit investigation, credit rating, and insurance institutions require graduate education (Ye et al., 2014).

According to the positioning of applied undergraduate education in our school, as well as our school's geographical location, there are four universities with the major of credit management, and two of them have obvious advantages in the field of bank credit management. We chose the "enterprises credit management", "financial institutions credit management" and "Credit rating agencies” as professional directions for differentiating competition and conducting a job analysis (table 2).

Table 2 Professional direction and job.

\begin{tabular}{|l|l|lr|}
\hline \multicolumn{2}{|c|}{ Direction } & \multicolumn{3}{|c|}{ Job } \\
\cline { 2 - 5 } & \multicolumn{1}{|c|}{ Primary } & \multicolumn{1}{c|}{ Intermediate } \\
\hline $\begin{array}{l}\text { Enterprise credit } \\
\text { management }\end{array}$ & $\begin{array}{l}\text { Credit files management; Credit } \\
\text { clerk; Accounting Clerk; Auditor; } \\
\text { Marketing jobs }\end{array}$ & $\begin{array}{l}\text { Credit customers manager; A/R } \\
\text { Clerk; Credit Manager }\end{array}$ \\
\hline $\begin{array}{l}\text { Financial } \\
\text { institutions credit } \\
\text { management }\end{array}$ & $\begin{array}{l}\text { Credit clerk; Credit card specialist; } \\
\text { Risk monitors; }\end{array}$ & $\begin{array}{l}\text { Investment adviser; Customer credit } \\
\text { management; risk } \\
\text { management }\end{array}$ \\
\hline $\begin{array}{l}\text { Credit rating } \\
\text { agencies }\end{array}$ & $\begin{array}{l}\text { Credit investigation specialist; } \\
\text { Marketing jobs }\end{array}$ & Credit rating analysts r risk \\
\hline
\end{tabular}




\subsection{Skills Training Curriculum Structure for Credit Management}

Using the previously built skills training framework, and taking into account the credit management professional direction and the jobs, we created the skills training curriculum structure for credit management (Figure 2).

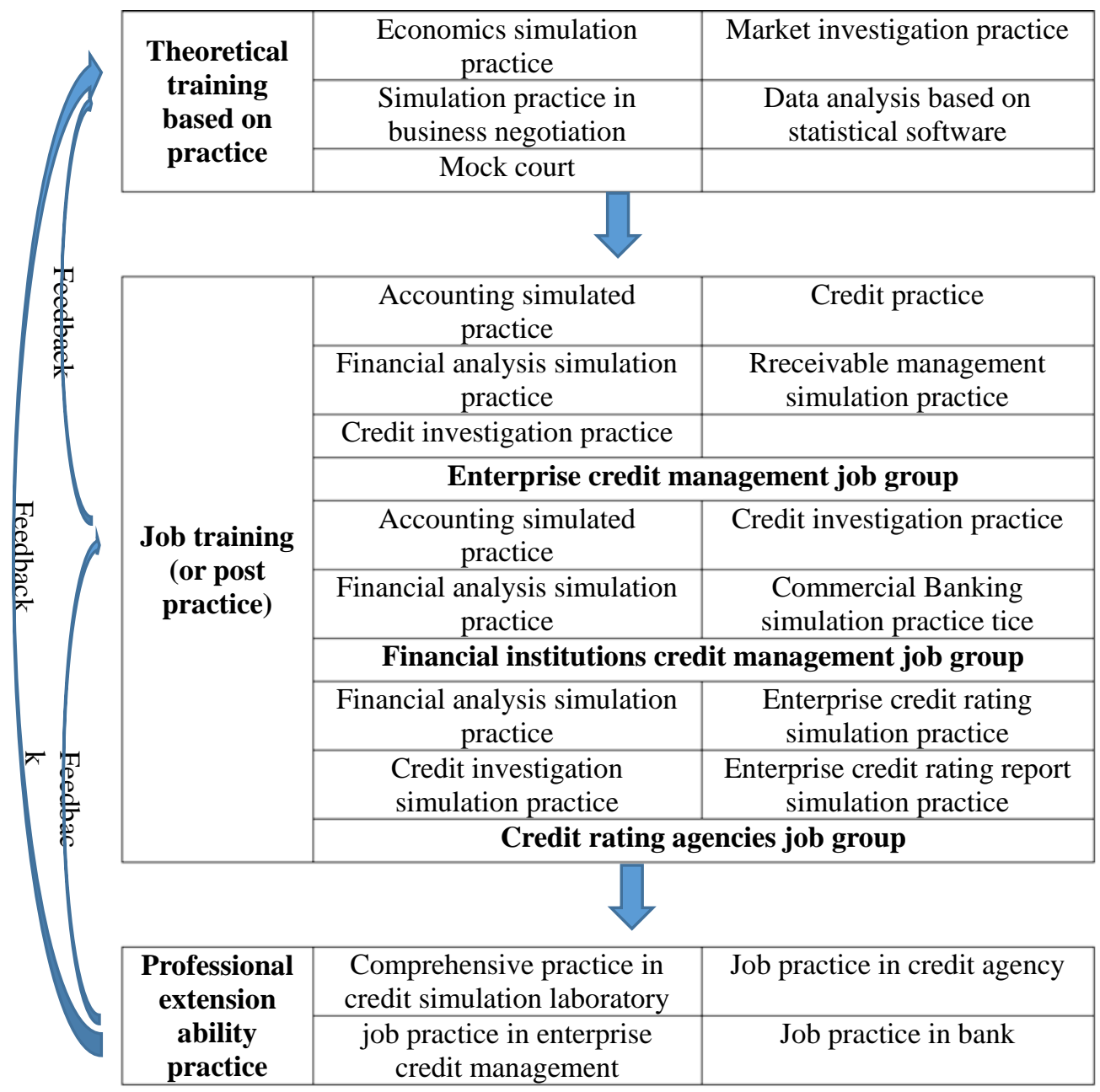

Figure 2 Skills training curriculum structure for credit management.

The skills training curriculum structure for credit management is ability oriented and position-oriented. Each link is closely related to the ability to develop. In the theoretical training based on practice, the target is defined as "making solid foundation, enhancing operation ability". Through the economics simulation practice, business negotiation, statistical analysis and market investigation practice, students will catch on to the basic theory they have learned. At the same time, they will be trained in their language expression ability, interpersonal ability, and ability to use basic software. In job training (or post practice), the practice ability of a certain position will be strengthened. For different credit associates, the different skills will be practiced. The professional extension ability practice must be targeted for "improving comprehensive ability". If possible, students take part in the job in enterprise or credit agencies. Through doing practical work in the real society, their practical ability will be improved again, and then, they may be promoted to relearning.

\section{The Implementation of Skills Training Curriculum Structure for Credit Management}

\subsection{School-Enterprise Cooperation}

It is not realistic that the implementation of skills training curriculum structure relies only on the teacher; instead, we need to find various ways to cooperate. Depending on the different situations of 
enterprises, we can have cooperation between different levels and different degrees. Cooperation should not only be limited to practice teaching, but also be extended to the whole teaching plan design, practice teaching arrangement and implementation stage. At present, we have the following kinds of cooperation modes (Table 3).

Table 3 School-enterprise cooperation modes.

\begin{tabular}{|l|l|}
\hline $\begin{array}{l}\text { Organization system of } \\
\text { school-enterprise cooperation }\end{array}$ & Operation mechanism of school-enterprise cooperation \\
\hline $\begin{array}{l}\text { Long-term agreement } \\
\text { cooperation }\end{array}$ & $\begin{array}{l}\text { An officially signed cooperative agreement; } \\
\text { Regular arrangements for students' training, teachers' study } \\
\text { and employment ; } \\
\text { Professionals teaching in skills training course regularly. }\end{array}$ \\
\hline Long-term stable cooperation & $\begin{array}{l}\text { Experts participate in teaching activities regularly; } \\
\text { Professional staff teach in skill training course regularly; } \\
\text { Arrange the internship unregularly; and } \\
\text { Provide A small amount of jobs. }\end{array}$ \\
\hline Long-term unstable cooperation & $\begin{array}{l}\text { Experts participate in deliberations of the training program; } \\
\text { Experts to participate in teaching activities unregularly; } \\
\text { Arrange the internship unregularly }\end{array}$ \\
\hline
\end{tabular}

\subsection{Use Of Campus Laboratories}

Limited by the internships that society can provide, students do not have a lot of opportunity to experience a real internship. The first two stages of practice can mostly be done through all kinds of credit management software, and actual data. The most important is the final stage, as its purpose is to develop comprehensive ability. Therefore, the final stages of practice should be best with a comprehensive credit management professional skill practice platform. This is a project we are studying currently.

\subsection{Result}

Since 2008, we revised the credit management professional teaching plan, and began to formulate the skills training curriculum structure practice, with the related courses implemented step by step. Courses in the area of theoretical training based on practice have all been run. Courses in the area of job training (or post practice) have mostly been implemented. Currently we are in construction of a comprehensive credit management professional skill practice platform which is a part of professional extension ability practice.

This skills training cultivates the students' the ability, enhances their professional skills, and improves their competitiveness in employment.

Employment data showed that the matching degree of employment improved when a student studies under "skills training curriculum structure". Here, the matching degree of employment refers to the jobs that students get that are related to the credit management profession. If the job is relevant to the credit management profession, we say that the job matches the profession. According to the analysis above, there are three professional directions: enterprise credit management, financial institutions credit management, and professional services. If jobs are considered relevant in these three areas, we say the job matches the profession. The matching degree of employment is based on the number of students who graduated with employment in the year divided by the total number of graduates in the year (excluding those who continue to study and who delay their graduation, but including those who are unemployed). The data comes from the employment commissioner of the School of Economics and Management. As the table shows, the students who graduated in 2010 and 2011 did not learn through the system. Students who graduated in 2012 have been trained on the program since first grade. Although the data is not very rigorous, to some extent it is still able to show that the skills training curriculum structure can improve professional skills. 
Table 4 Matching degree.

\begin{tabular}{|c|c|c|c|c|c|c|c|c|}
\hline Year & 2010 & 2011 & 2012 & 2013 & 2014 & 2015 & 2016 & 2017 \\
\hline Matching degree & $35.48 \%$ & $27.53 \%$ & $39.77 \%$ & $45.94 \%$ & $36 \%$ & $51.57 \%$ & $36.36 \%$ & $43.75 \%$ \\
\hline
\end{tabular}

\section{Conclusion}

The successful practice of the skills training framework in credit management presented in this paper shows that the framework can be applied in other similar areas of soft science.

When using the framework in different areas to structure a professional skills training curriculum system, what should be considered first and foremost is the professional direction and training goals, and then the job analysis. Professional direction should be consistent with the job, and the skills training under this framework helps to meet the needs of society. Students that will be widely accepted by employers have become a necessity.

In professional skills training curriculum structure practice, campus training platform construction is as important as school-enterprise cooperation. In practice, various methods can be adopted according to specific professional characteristics. But for a soft science field, the school cooperating with the enterprise to develop a simulation practice platform is a good way to develop direction.

In this paper, we only discussed the skills training curriculum structure at a whole level. In reality, in implementing the skills training curriculum structure, studying at the unit or course level is important as well.

\section{Acknowledgements}

Thanks the Financial Discipline of Shanghai Polytechnic University (XXKPY1602) for financial support of this research.

\section{References}

[1] Wang, C. L. (2015). Mapping or tracing? Rethinking curriculum mapping in higher education. Studies in Higher Education, 40(6), 1550-1559.

[2] Gong, J. M., \& Xiao B. L. (2015). The Development of Curriculum Mapping in Universities in [3] Chinese Taipei and Its Implications for Mainland Universities. Higher Education of Sciences, 2015(02), 20-24.

[4] Delgaty, L.(2009). Curriculum Mapping: Are You Thinking What I'm Thinking? A Visual Comparison of Standardized, Prescriptive Programmes, 2009(6), 35-58.

[5] Watts, L. \& Hodgson, D. (2015). Whole Curriculum Mapping of Assessment: Cartographies of Assessment and Learning. Social Work Education, 34(6), 682-699.

[6] Ministry of Education of the People's Republic of China. (2010). the National Medium and Long-term Education Reform and Development Plan (2010-2020). Downloaded from http://www.moe.gov.cn/srcsite/A01/s7048/201007/t20100729_171904.html.

[7] Ministry of Education of the People's Republic of China. (2015). A mid-term review of the education programming outline (2010-2020) - Professional education assessment report. Downloaded

http://www.moe.gov.cn/jyb_xwfb/xw_fbh/moe_2069/xwfbh_2015n/xwfb_151202/151202_sfcl/201 512/t20151202_222297.html.

[8] Zhou, S. P. (2013). Open University Major Construction Based on Course Map —Taking Credit Management Major as an Example. Journal of Tianjin Radio \& TV University, 17(2), 30-36.

[9] Ye, X. R., Tang, M. Q. \& Guo, J. L. (2014). Transformation from Undergraduate Education to 
Vocational Education and Curriculum Reform. Finance Teaching and Research, 2014(3), 68-71.

[10] Wang, Y. H. (2014). Skills Training Under Professional Education. Proceedings of 2014 4th International Conference on Applied Social Science, 388-393.

[11] Pan, Y. J. \& Liao, C.J. (2014). Quality and Assessment of Practice-oriented Undergraduate Talents Based on Social Needs. Higher Education Development and Evaluation, 30(5), 88-94. 